\title{
Determining the influence of eucalypt lignin composition in paper pulp yield using Py-GC/MS
}

\author{
José C. del Río ${ }^{\mathrm{a}, *}$, Ana Gutiérrez ${ }^{\mathrm{a}}$, Marina Hernando ${ }^{\mathrm{b}}$, Pedro Landín ${ }^{\mathrm{b}}$, \\ Javier Romero $^{\mathrm{b}}$, Ángel T. Martínez ${ }^{\mathrm{c}}$ \\ ${ }^{a}$ Instituto de Recursos Naturales y Agrobiología de Sevilla, CSIC P.O. Box 1052, 41080 Seville, Spain \\ ${ }^{\mathrm{b}}$ ENCE-CIT, Ctra. Campañó, Ribeiro-Vao, 36157 Pontevedra, Spain \\ ${ }^{\mathrm{c}}$ Centro de Investigaciones Biológicas, CSIC Ramiro de Maeztu 9, E-28040 Madrid, Spain
}

Received 7 June 2004; accepted 14 October 2004

Available online 11 March 2005

\begin{abstract}
A set of Eucalyptus globulus woods from different origins and growth conditions, giving a wide range of pulp yields (from 40 to $60 \%$ ) upon kraft cooking, was analyzed using Py-GC/MS. The carbohydrate-derived compounds and the compounds derived from syringyl (S) and guaiacyl (G) lignin units were analyzed and the lignin/carbohydrate and S/G ratios determined. Eucalypt woods giving higher pulp yield released higher amounts of S-type compounds upon Py-GC/MS. A significant correlation was observed between pulp yield and the lignin composition in terms of the S/G ratio. By contrast, the lignin/carbohydrate ratio obtained by Py-GC/MS did not show a significant correlation with the pulp yield. This indicates that the lignin composition is a more important parameter influencing pulp yield than the lignin content. (C) 2005 Elsevier B.V. All rights reserved.
\end{abstract}

Keywords: Eucalyptus globulus; Wood; Lignin; S/G ratio; Pulp yield; Delignification; Pyrolysis

\section{Introduction}

Chemical pulping involves the separation of cellulosic fibers and the removal of lignin by using an alkali solution and high temperatures and pressures. A major determinant of the economics of a kraft pulping operation is the yield of pulp per ton of wood. The content and chemical structure of wood components, in particular lignin content and its composition in terms of its $p$-hydroxyphenyl $(\mathrm{H})$, guaiacyl (G; 4-hydroxy, 3-methoxyphenyl) and syringyl (S; 4hydroxy, 3,5-dimethoxyphenyl) moieties could be important parameters in pulp production in view of delignification rates, chemical consumption and pulp yields $[1,2]$. In hardwoods, such as eucalyptus, lignins are made up of $\mathrm{S}$ and $\mathrm{G}$ units in varying ratios, whereas softwood lignin is made of $\mathrm{G}$ units and small amount of $\mathrm{H}$ units, and grass lignins include the three units [3]. The higher reactivity of the $\mathrm{S}$ lignin with respect to the $\mathrm{G}$ lignin in alkaline systems is

\footnotetext{
* Corresponding author. Tel.: +34 95462 4711; fax: +34 954624002. E-mail address: delrio@irnase.csic.es (J.C. del Río).
}

known [4]. Therefore, the $S / G$ ratio in hardwood lignin should affect the pulping efficiency [5].

In breeding programmes where tree clones suitable for pulp production are selected, it is important to discriminate the best clones (giving the highest pulp yield) based on the chemical structure of lignin. Ideally, this should be done by analyzing a small wood sample obtained from the trunk without the need of cutting down the whole tree for cooking and direct estimation of yield. Several chemical degradative methods have been used for determining the lignin S/G ratio in woods. Permanganate and alkaline nitrobenzene oxidation [6,7], as well as acidolysis [8] and thioacidolysis [9,10] or $\mathrm{CuO}$ oxidation $[11,12]$ have been utilized for determining the $\mathrm{S} / \mathrm{G}$ ratio. However, these methods often require tedious and time-consuming procedures and need large amounts of wood sample (around $100 \mathrm{mg}$ ). Spectroscopic methods, such as FTIR [13], or solid-state ${ }^{13} \mathrm{C}$ NMR [7,12,14-17] have been used to determine the $\mathrm{S} / \mathrm{G}$ ratio in various hardwoods. However, it is often difficult to determine the precise $S / G$ ratio in lignin owing to both insufficient sensitivity and poor resolution in the spectra, and lignin 
Table 1

List of wood samples of two E. globulus subspecies with different pulp yields, and values of the syringyl/guaiacyl (S/G) and lignin/carbohydrate (L/HC) molar ratios calculated upon Py-GC/MS

\begin{tabular}{|c|c|c|c|c|c|c|c|c|c|c|}
\hline \multirow{3}{*}{$\begin{array}{l}\text { Sample } \\
\text { No. }\end{array}$} & \multirow[t]{3}{*}{ Subspecies } & \multirow[t]{3}{*}{ Reference } & \multirow{3}{*}{$\begin{array}{l}\text { Density } \\
\left(\mathrm{kg} / \mathrm{m}^{3}\right)\end{array}$} & \multirow{3}{*}{$\begin{array}{l}\text { Active } \\
\text { alkali }(\%)\end{array}$} & \multirow{3}{*}{$\begin{array}{l}\text { Pulp } \\
\text { yield (\%) }\end{array}$} & \multirow{3}{*}{$\begin{array}{l}\text { Viscosity } \\
(\mathrm{mL} / \mathrm{g})\end{array}$} & \multicolumn{4}{|c|}{ Py-GC/MS } \\
\hline & & & & & & & \multicolumn{2}{|l|}{$\mathrm{S} / \mathrm{G}$} & \multicolumn{2}{|l|}{$\mathrm{L} / \mathrm{HC}$} \\
\hline & & & & & & & Average & $\mathrm{CV}(\%)$ & Average & $\mathrm{CV}(\%)$ \\
\hline 1 & E. globulus ssp. globulus & T5 & 580 & 13.0 & 59.6 & 1451 & 5.5 & 3.3 & 0.94 & 5.5 \\
\hline 2 & E. globulus ssp. globulus & T6 & 600 & 13.5 & 58.9 & 1348 & 5.0 & 3.0 & 0.75 & 3.5 \\
\hline 3 & E. globulus ssp. globulus & Plus 522 & 567 & 12.0 & 55.8 & 1528 & 6.4 & 1.0 & 1.05 & 7.7 \\
\hline 4 & E. globulus ssp. globulus & Elite 2002 & 556 & 14.0 & 55.2 & 1369 & 5.0 & 2.7 & 0.76 & 4.4 \\
\hline 5 & E. globulus ssp. globulus & Elite 5002 & 438 & 14.0 & 54.1 & 1418 & 4.0 & 0.5 & 1.13 & 1.5 \\
\hline 6 & E. globulus ssp. globulus & Elite 4009 & 556 & 16.0 & 52.5 & 1217 & 4.1 & 0.5 & 0.74 & 5.6 \\
\hline 7 & E. globulus ssp. globulus & Elite 4500 & 477 & 16.0 & 49.8 & 1294 & 4.3 & 4.8 & 1.31 & 9.2 \\
\hline 8 & E. globulus ssp. globulus & 115-2-PM 10 & 578 & 17.0 & 49.1 & 1174 & 5.3 & 2.4 & 1.43 & 5.2 \\
\hline 9 & E. globulus ssp. globulus & 334-1-AR 2 & 613 & 20.0 & 46.6 & 1143 & 4.6 & 1.3 & 0.86 & 15.3 \\
\hline 10 & E. globulus ssp. pseudoglobulus & 2 & 547 & 22.0 & 44.8 & 1135 & 3.5 & 4.0 & 0.71 & 8.4 \\
\hline 11 & E. globulus ssp. pseudoglobulus & 4 & 663 & 24.0 & 42.0 & 1089 & 3.5 & 2.5 & 0.58 & 5.8 \\
\hline 12 & E. globulus ssp. pseudoglobulus & 6 & 665 & 26.0 & 40.8 & 1062 & 4.0 & 2.2 & 0.64 & 5.8 \\
\hline
\end{tabular}

The reproducibility of the data is reflected in the coefficient of variation $(\mathrm{CV}, \%)$.

extraction is always required. On the other hand, pyrolysisgas chromatography/mass spectrometry (Py-GC/MS) is rapid and highly sensitive for characterizing the chemical structure of lignin, which allows the analysis of very small amounts of sample without prior manipulation and/or isolation [18-20]. Py-GC/MS has also been successfully used for the calculation of the $\mathrm{S} / \mathrm{G}$ ratios in wood, and especially in eucalypt species [21-23].

The objective of this work is to evaluate the influence of lignin composition (in terms of the S/G ratio observed by PyGC/MS) in the pulp yield. A series of Eucalyptus globulus Labill. wood samples from different origins and growth conditions, which are used as raw material from paper pulp production with a wide range of pulp yields upon kraft cooking, have been selected for this study.

\section{Material and methods}

Wood samples taken from 12 E. globulus trees (8-11year-old) from different origins and growth conditions, which gave very different pulp yields upon kraft cooking, were used for this study. The wood samples (discs collected at a standard height) were chopped and mixed with different alkali charges to achieve pulp kappa number 16. Kraft cooking were performed using $200 \mathrm{~g}$ of wood under the following cooking conditions: $3.5: 1$ liquor to wood ratio; $165{ }^{\circ} \mathrm{C}$ cooking temperature; cycle: 90 min heating up and $50 \mathrm{~min}$ at cooking temperature; $25 \%$ sulphidity; active alkali variable depending on the cooking. For Py-GC/MS analysis, the eucalypt samples were milled into fine powders. Five replicates were performed for each analysis.

\subsection{Pyrolysis-gas chromatography/mass spectrometry}

Analytical pyrolysis was performed using a CDS Pyroprobe AS-2500 Autosampler. The sample (typically
$100 \mu \mathrm{g}$ ) was placed in a quartz tube, $2 \mathrm{~mm} \times 40 \mathrm{~mm}$ and put into the sample tray. The pyrolysis was carried out at $550{ }^{\circ} \mathrm{C}$ for $10 \mathrm{~s}$. The pyrolysis chamber was kept at $250^{\circ} \mathrm{C}$ and purged with helium in order to transfer the pyrolysis products as quickly as possible to the GC column. The pyrolyser was connected to an Agilent 6890 gas chromatograph equipped with an on-column injector and a fused silica capillary column (DV-1701, $60 \mathrm{~m} \times 0.25 \mathrm{~mm}$ ID, $0.25 \mu \mathrm{m}$ film thickness) coupled to an Agilent 5973N mass spectrometer. The chromatograph was programmed from $45^{\circ} \mathrm{C}$ (4 min) to $280{ }^{\circ} \mathrm{C}$ at a rate of $4{ }^{\circ} \mathrm{C} \mathrm{min}^{-1}$. The final temperature was held for $15 \mathrm{~min}$. The injector was set at $250{ }^{\circ} \mathrm{C}$, while the CG/MS interface was kept at $280{ }^{\circ} \mathrm{C}$. The compounds were identified by comparing the mass spectra thus obtained with those of the Wiley computer libraries, by mass fragmentography and by comparison with literature data $[18,19]$.

\section{Results and discussion}

The series of eucalypt woods selected for this study corresponded to two E. globulus subspecies, namely $E$. globulus ssp. globulus Labill. and E. globulus ssp. pseudoglobulus Naudin ex Maiden (Table 1). The woods gave a broad range of pulp yields upon kraft cooking. In order to investigate whether the differences in pulp yields are related to the content and composition of the main wood components, carbohydrates and lignin, the wood samples were analyzed by Py-GC/MS. Fig. 1 shows a representative pyrogram of an eucalypt wood sample. The compounds released arise mainly from the carbohydrate and lignin moieties. The identity of the compounds identified is listed in Table 2. The main lignin-derived compounds are guaiacol (7), 4-methylguaiacol (8), 4-vinylguaiacol (12), syringol (15), trans-isoeugenol (18), 4-methylsyringol (19), 4ethylsyringol (22), 4-vinylsyringol (24), 4-allylsyringol 


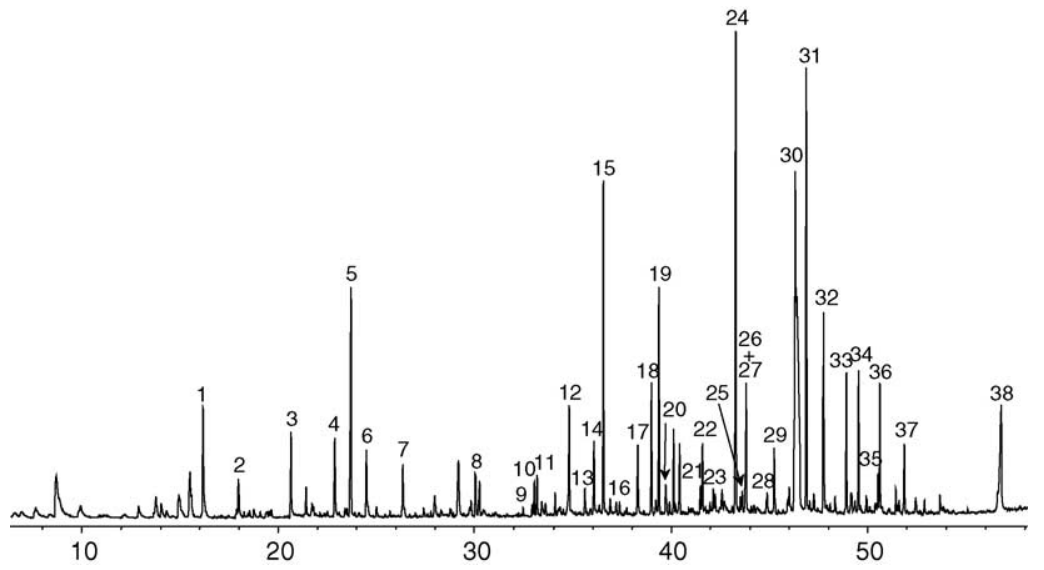

Fig. 1. Py-GC/MS chromatogram of a representative sample of E. globulus wood (sample 1). The numbers refer to the compounds listed in Table 2.

Table 2

List of compounds identified in the Py-GC/MS of E. globulus wood

\begin{tabular}{|c|c|c|c|c|c|}
\hline No. & Mass fragments & Compound & Formula & MW & Origin \\
\hline 1 & $39 / 95 / 96$ & Furfural & $\mathrm{C}_{5} \mathrm{H}_{4} \mathrm{O}_{2}$ & 96 & $\mathrm{C}$ \\
\hline 2 & $53 / 69 / 81 / 97 / 98$ & Furfuryl alcohol & $\mathrm{C}_{5} \mathrm{H}_{6} \mathrm{O}_{2}$ & 98 & $\mathrm{C}$ \\
\hline 3 & $55 / 69 / 70 / 98$ & 2,3-Dihydro-5-methylfuran-2-one & $\mathrm{C}_{5} \mathrm{H}_{6} \mathrm{O}_{2}$ & 98 & $\mathrm{C}$ \\
\hline 4 & $55 / 84$ & $(5 H)$-Furan-2-one & $\mathrm{C}_{4} \mathrm{H}_{4} \mathrm{O}_{2}$ & 84 & $\mathrm{C}$ \\
\hline 5 & $57 / 58 / 85 / 114$ & 4-Hydroxy-5,6-dihydro-(2H)-pyran-2-one & $\mathrm{C}_{5} \mathrm{H}_{6} \mathrm{O}_{3}$ & 114 & $\mathrm{C}$ \\
\hline 6 & $55 / 71 / 84 / 112$ & 3-Hydroxy-2-methyl-2-cyclopenten-1-one & $\mathrm{C}_{6} \mathrm{H}_{8} \mathrm{O}_{2}$ & 112 & $\mathrm{C}$ \\
\hline 7 & $81 / 109 / 124$ & Guaiacol & $\mathrm{C}_{7} \mathrm{H}_{8} \mathrm{O}_{2}$ & 124 & LG \\
\hline 8 & $95 / 123 / 138$ & 4-Methylguaiacol & $\mathrm{C}_{8} \mathrm{H}_{10} \mathrm{O}_{2}$ & 138 & LG \\
\hline 9 & $122 / 137 / 152$ & 4-Ethylguaiacol & $\mathrm{C}_{9} \mathrm{H}_{12} \mathrm{O}_{2}$ & 152 & LG \\
\hline 10 & $57 / 69 / 70 / 82 / 85$ & 5-Hydroxymethyl-2-tetrahydrofuraldehyde-3-one & $\mathrm{C}_{6} \mathrm{H}_{8} \mathrm{O}_{4}$ & 144 & $\mathrm{C}$ \\
\hline 11 & $56 / 84 / 114$ & Dihydrohydroxypyran-1-one & $\mathrm{C}_{5} \mathrm{H}_{6} \mathrm{O}_{3}$ & 114 & $\mathrm{C}$ \\
\hline 12 & $107 / 135 / 150$ & 4-Vinylguaiacol & $\mathrm{C}_{9} \mathrm{H}_{10} \mathrm{O}_{2}$ & 150 & LG \\
\hline 13 & $131 / 149 / 164$ & Eugenol & $\mathrm{C}_{10} \mathrm{H}_{12} \mathrm{O}_{2}$ & 164 & LG \\
\hline 14 & $69 / 97 / 109 / 126$ & 5-Hydroxymethyl-2-furfuraldehyde & $\mathrm{C}_{6} \mathrm{H}_{6} \mathrm{O}_{3}$ & 126 & $\mathrm{C}$ \\
\hline 15 & $111 / 139 / 154$ & Syringol & $\mathrm{C}_{8} \mathrm{H}_{10} \mathrm{O}_{3}$ & 154 & LS \\
\hline 16 & $131 / 149 / 164$ & cis-Isoeugenol & $\mathrm{C}_{10} \mathrm{H}_{12} \mathrm{O}_{2}$ & 164 & LG \\
\hline 17 & $43 / 87 / 97 / 113 / 144$ & 2-Hydroxymethyl-5-hydroxy-2,3-dihydro-(4H)-pyran-4-one & $\mathrm{C}_{5} \mathrm{H}_{8} \mathrm{O}_{4}$ & 144 & $\mathrm{C}$ \\
\hline 18 & $131 / 149 / 164$ & trans-Isoeugenol & $\mathrm{C}_{10} \mathrm{H}_{12} \mathrm{O}_{2}$ & 164 & LG \\
\hline 19 & $125 / 153 / 168$ & 4-Methylsyringol & $\mathrm{C}_{9} \mathrm{H}_{12} \mathrm{O}_{2}$ & 168 & LS \\
\hline 20 & $109 / 151 / 152$ & Vanillin & $\mathrm{C}_{8} \mathrm{H}_{8} \mathrm{O}_{3}$ & 152 & LG \\
\hline 21 & $122 / 137 / 166$ & Homovanillin & $\mathrm{C}_{10} \mathrm{H}_{14} \mathrm{O}_{2}$ & 166 & LG \\
\hline 22 & $167 / 182$ & 4-Ethylsyringol & $\mathrm{C}_{10} \mathrm{H}_{14} \mathrm{O}_{3}$ & 182 & LS \\
\hline 23 & $123 / 151 / 166$ & Acetoguaiacone & $\mathrm{C}_{9} \mathrm{H}_{10} \mathrm{O}_{3}$ & 166 & LG \\
\hline 24 & $137 / 165 / 180$ & 4-Vinylsyringol & $\mathrm{C}_{10} \mathrm{H}_{12} \mathrm{O}_{3}$ & 180 & LS \\
\hline 25 & $122 / 137 / 180$ & Guaiacylacetone & $\mathrm{C}_{10} \mathrm{H}_{12} \mathrm{O}_{3}$ & 180 & LG \\
\hline 26 & $167 / 179 / 194$ & 4-Allylsyringol & $\mathrm{C}_{11} \mathrm{H}_{14} \mathrm{O}_{3}$ & 194 & LS \\
\hline 27 & $123 / 167 / 196$ & 4-Propylsyringol & $\mathrm{C}_{11} \mathrm{H}_{16} \mathrm{O}_{3}$ & 196 & LS \\
\hline 28 & $123 / 151 / 180$ & Propiovanillone & $\mathrm{C}_{10} \mathrm{H}_{12} \mathrm{O}_{3}$ & 180 & LG \\
\hline 29 & $167 / 179 / 194$ & cis-4-Propenylsyringol & $\mathrm{C}_{11} \mathrm{H}_{14} \mathrm{O}_{3}$ & 194 & LS \\
\hline 30 & $57 / 60 / 73 / 98$ & Levoglucosane & $\mathrm{C}_{6} \mathrm{H}_{10} \mathrm{O}_{5}$ & 162 & $\mathrm{C}$ \\
\hline 31 & $167 / 179 / 194$ & trans-4-Propenylsyringol & $\mathrm{C}_{11} \mathrm{H}_{14} \mathrm{O}_{3}$ & 194 & LS \\
\hline 32 & $167 / 181 / 182$ & Syringaldehyde & $\mathrm{C}_{9} \mathrm{H}_{10} \mathrm{O}_{4}$ & 182 & LS \\
\hline 33 & $167 / 196$ & Homosyringaldehyde & $\mathrm{C}_{10} \mathrm{H}_{12} \mathrm{O}_{4}$ & 196 & LS \\
\hline 34 & $153 / 181 / 196$ & Acetosyringone & $\mathrm{C}_{10} \mathrm{H}_{12} \mathrm{O}_{4}$ & 196 & LS \\
\hline 35 & $107 / 135 / 147 / 178$ & Coniferylaldehyde & $\mathrm{C}_{10} \mathrm{H}_{10} \mathrm{O}_{3}$ & 178 & LG \\
\hline 36 & $167 / 210$ & Syringylacetone & $\mathrm{C}_{11} \mathrm{H}_{14} \mathrm{O}_{4}$ & 210 & LS \\
\hline 37 & $181 / 210$ & Propiosyringone & $\mathrm{C}_{11} \mathrm{H}_{14} \mathrm{O}_{5}$ & 210 & LS \\
\hline 38 & $137 / 165 / 180 / 180 / 208$ & Sinapaldehyde & $\mathrm{C}_{11} \mathrm{H}_{12} \mathrm{O}_{4}$ & 208 & LS \\
\hline
\end{tabular}

C: cellulose; LG: lignin guaiacyl units; LS: lignin syringyl units. 
(26), cis- and trans-4-propenylsyringol (29 and 31), syringaldehyde (32), homosyringaldehyde (33), acetosyringone (34), syringylacetone (36), propiosyringone (37) and sinapaldehyde (38). In all cases, the lignin-derived S-type phenols are present in higher abundances than the respective G-type phenols. Among the carbohydrate-derived compounds, the main ones are furfural (1), 2,3-dihydro-5methylfuran-2-one (3), $(5 H)$-furan-2-one (4), 4-hydroxy5,6-dihydro-(2H)-pyran-2-one (5), 3-hydroxy-2-methyl-2cyclopenten-1-one (6), 5-hydroxymethyl-2-furfuraldehyde (14), 2-hydroxymethyl-5-hydroxy-2,3-dihydro-(4H)-pyran4-one (17) and levoglucosane (30). Relative peak molar areas were calculated for carbohydrate, and lignin G- and Stype degradation products. The lignin $\mathrm{S} / \mathrm{G}$ and lignin/ carbohydrate $(\mathrm{L} / \mathrm{HC})$ ratios were determined for each sample and the average for the five replicates calculated. It must be noted here that the observed $\mathrm{L} / \mathrm{HC}$ ratio does not reflect the real content of each moiety since pyrolysis is known to highly underestimate the cellulose content due to intense charring and extensive degradation to non-chromatographied products. However, the $\mathrm{L} / \mathrm{HC}$ ratio observed after pyrolysis can still be used for comparison of the relative amounts of each moiety.

Table 1 shows the values for the $S / G$ and lignin/ carbohydrate ratios calculated upon Py-GC/MS. The good reproducibility of the Py-GC/MS data is reflected in the coefficient of variation of both the S/G and L/HC ratios. A better reproducibility is observed for the $\mathrm{S} / \mathrm{G}$ ratio (less than $5 \%$ ) than for the L/HC ratio. The $\mathrm{S} / \mathrm{G}$ ratios of the $E$. globulus wood samples selected for this study ranged from 3.5 to 6.4 , while the lignin/carbohydrate ratio ranged from 0.58 to 1.43 , indicating the high variability of the carbohydrate and lignin content and lignin composition among samples from the same wood species. It has already been reported that the lignin S/G ratio in eucalypt wood exhibits considerable variation depending on the origins of the tree [22], in trees from the same origin [23] and even within the same tree [21].

In general, it can be observed that wood samples having higher pulp yields (i.e. E. globulus ssp. globulus T5, T6 and Plus no. 522 woods; samples 1-3) generally present higher S/G ratios than those wood samples having lower pulp yields (i.e. the E. globulus ssp. pseudoglobulus 2, 4 and 6 woods; samples 10-12). These results seem to indicate that the lignin composition in terms of the $S / G$ ratio can be correlated with the pulp yield. The plot of the pulp yield versus the $\mathrm{S} / \mathrm{G}$ ratio estimated upon $\mathrm{Py}-\mathrm{GC} / \mathrm{MS}$ is shown in Fig. 2. A significant correlation $(r=0.680 ; P<0.02)$ was observed between the lignin compositions of the different woods, as reflected by the S/G ratio, and the pulp yield for the series of eucalypt wood samples studied. Pulp yield increases as the $S / G$ ratio of a wood increases. This is explained because the $\mathrm{S}$ units are mainly linked by more labile ether bonds (at the $\mathrm{C} 4$ position of the aromatic rings) whereas $\mathrm{C}-\mathrm{C}$ linkages (at the free $\mathrm{C} 5$ position) also exist between the $\mathrm{G}$ units, as described in lignin structural models

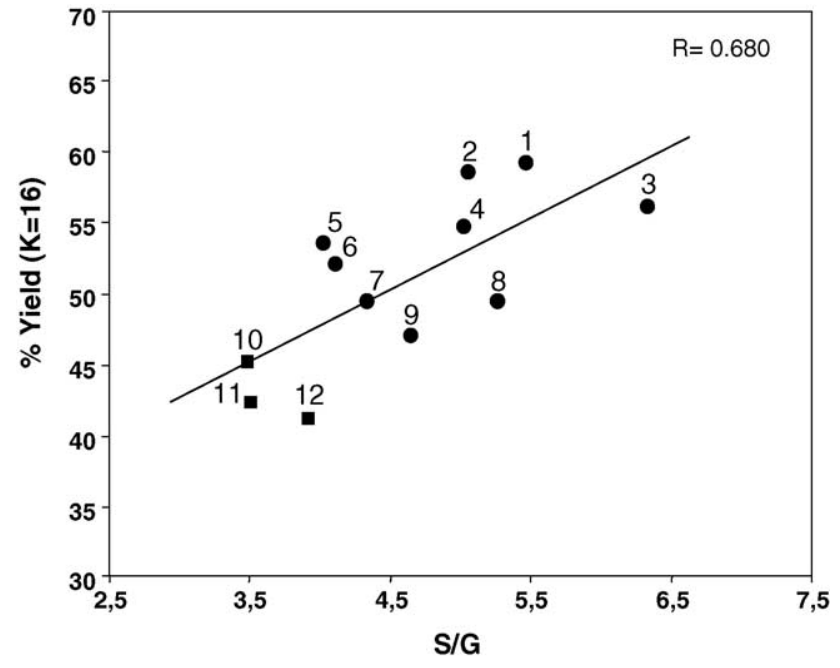

Fig. 2. Plot of the pulp yield of the selected samples vs. the S/G ratio estimated upon Py-GC/MS. The numbers refer to the wood samples listed in Table 1. Key labels for the different populations are: E. globulus ssp. globulus wood (O) and E. globulus ssp. pseudoglobulus wood ( $\mathbf{\square}$ ).

$[24,25]$. Higher proportions of S-lignin units allow their easier removal during kraft pulping. This results in lower alkali consumption during pulping, less degradation of cellulose and, consequently, higher pulp yields. In any case, the significant regression coefficient value obtained confirms that the lignin composition is an important parameter that affects pulp yield. However, other factors besides the lignin composition seem to affect the pulp yield. Our results with E. globulus woods and pulps are in agreement with previous results [26-28], including those from GonzálezVila et al. [16] that showed a correlation between lignin S/G ratio in different eucalypt species, as estimated by pyrolysis in the presence of tetramethylammonium hydroxide, and the ease of delignification estimated as the active alkali used.

In contrast, a correlation between the lignin and carbohydrate contents (estimated as the L/HC ratio calculated upon Py-GC/MS) and the pulp yield, was not observed (Fig. 3). This fact seems to indicate that the lignin composition is a more important parameter influencing pulp yield than the lignin content estimated upon Py-GC/MS. The three E. globulus ssp. pseudoglobulus woods (samples 1012) seem to be the responsible for the rare regression observed between L/HC ratio and pulp yield (woods with high lignin content have higher pulp yields) since they show very low pulp yields despite having very low $\mathrm{L} / \mathrm{HC}$ ratios. This low yield (regardless of their higher content in carbohydrates) can be explained because these samples show the lowest $\mathrm{S} / \mathrm{G}$ ratio among all the analyzed samples. On the other hand, the contrary occurs with sample 8 or sample 3, that despite having high lignin/carbohydrate values (low cellulose content), they present higher yields probably due to their very high $\mathrm{S} / \mathrm{G}$ ratio. This fact is also observed in Fig. 4 that shows the plot of the S/G ratio versus the $\mathrm{L} / \mathrm{HC}$ ratio for the different wood samples. It can be observed that a correlation exists between both parameters. 


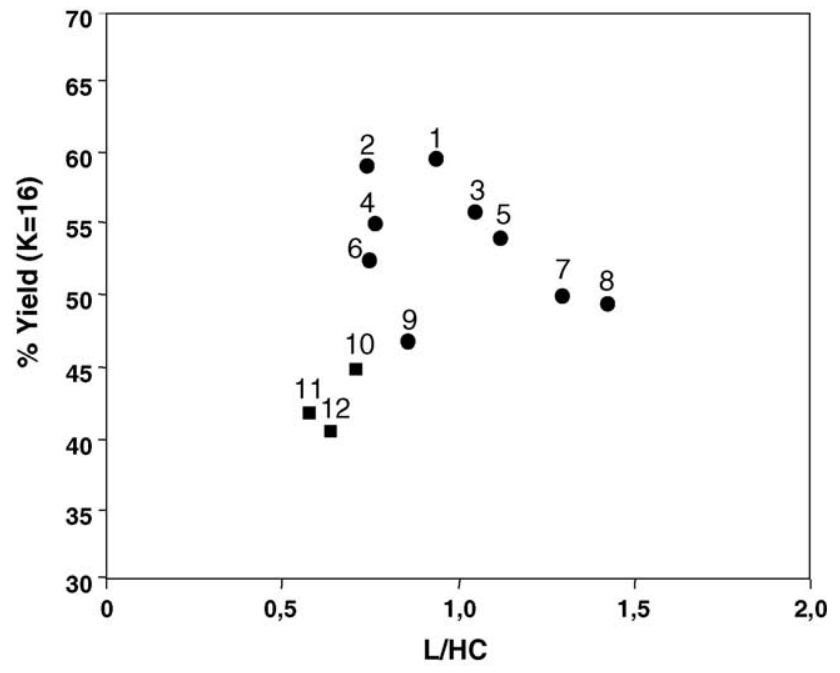

Fig. 3. Plot of the pulp yield of the selected samples vs. the lignin/ carbohydrate ratio estimated upon Py-GC/MS. The numbers refer to the wood samples listed in Table 1. Key labels for the different populations are: E. globulus ssp. globulus wood (O) and E. globulus ssp. pseudoglobulus wood (ם).

In general, wood samples with higher lignin content (and therefore lower cellulose content) have higher S/G ratio, which will be therefore easily delignified.

The data reported here gives an evidence of the influence of the lignin composition (S/G ratio) of E. globulus wood in the pulp yield. This allows considering the inclusion of lignin composition, in terms of the $\mathrm{S} / \mathrm{G}$ ratio, as a selection parameter in clonal breeding programs for pulpwood production. Since Py-GC/MS analysis only needs a minimum amount of sample, it can be applied to nondestructive sampling in the tree and, therefore, makes it a useful procedure to asses the $\mathrm{S} / \mathrm{G}$ ratio of a large number of

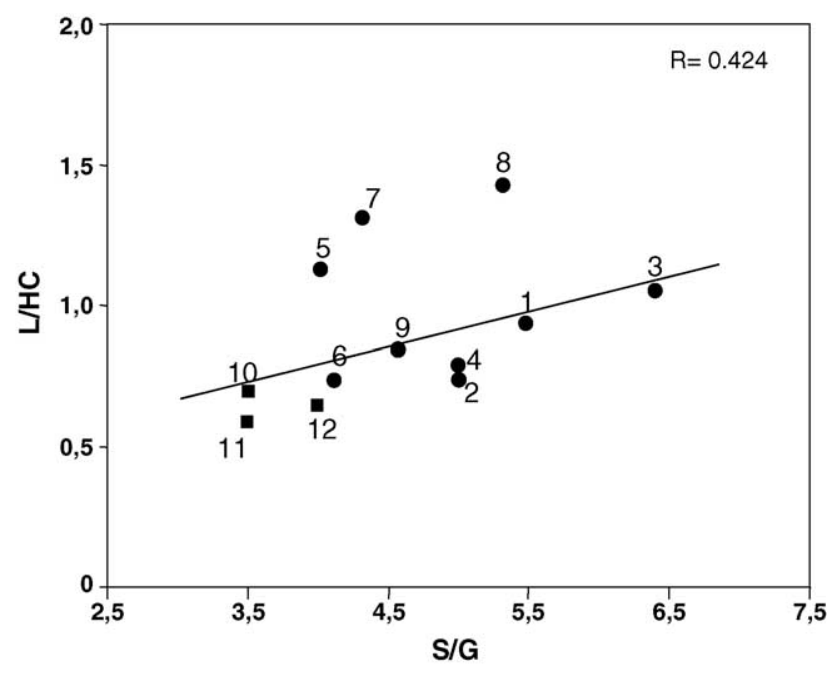

Fig. 4. Plot of the $\mathrm{S} / \mathrm{G}$ ratio vs. the lignin/carbohydrate ratio estimated upon Py-GC/MS for the different E. globulus wood samples selected for this study. The numbers refer to the wood samples listed in Table 1. Key labels for the different populations are: E. globulus ssp. globulus wood (O) and $E$. globulus ssp. pseudoglobulus wood ( $\mathbf{\square})$. samples. However, correlation levels shown above do not allow using Py-GC/MS as a unique parameter to predict the pulp yield of different woods. Combination with other techniques, such as near infrared (NIR) [29-31] or FTRaman spectroscopy [32,33] could be appropriate in tree breeding programmes.

\section{Acknowledgements}

This study has been supported by Grupo Empresarial ENCE S.A. and the Spanish Ministerio de Ciencia y Tecnología (MCyT) (project AGL2002-00393). A.G. acknowledges a "Ramón y Cajal" contract of the Spanish MCyT.

\section{References}

[1] H. Chang, K.V. Sarkanen, Tappi J. 56 (1973) 132-134.

[2] J.C. del Río, A. Gutiérrez, M.J. Martínez, A.T. Martínez, J. Anal. Appl. Pyrol. 58/59 (2001) 441-453.

[3] K.V. Sarkanen, H.L. Hergert, in: K.V. Sarkanen, C.H. Ludwig (Eds.), Lignins-Occurrence, Formation, Structure and Reaction, WileyInterscience, New York, 1971, pp. 43-94.

[4] Y. Tsutsumi, R. Kondo, K. Sakai, H. Imamura, Holzforschung 49 (1995) 423-428.

[5] D. Collins, C. Pilotti, A. Wallis, Appita J. 43 (1990) 193-198.

[6] M. Tanahashi, T. Higuchi, Meth. Enzymol. 161 (1992) 101-113.

[7] Y. Xie, S. Yasuda, Nordic Pulp Pap. Res. J. 19 (2004) 18-21.

[8] K. Lundquist, in: S.Y. Lin, C.W. Dence (Eds.), Methods in Lignin Chemistry, Springer-Verlag, Berlin, 1992, pp. 289-300.

[9] C. Lapierre, B. Monties, C. Rolando, Holzforschung 40 (1986) 113 119.

[10] T. Ona, T. Sonoda, K. Ito, M. Shibata, Holzforschung 51 (1997) 396404.

[11] J.I. Hedges, D.C. Mann, Geochim. Cosmochim. Acta 43 (1979) $1803-$ 1807.

[12] A.T. Martínez, A.E. González, A. Prieto, F.J. González-Vila, R. Fründ, Holzforschung 45 (1991) 279-284.

[13] O. Faix, Holzforschung 45 (1991) 21-27.

[14] H.H. Nimz, D. Robert, O. Faix, M. Nemr, Holzforschung 35 (1981) 16-26.

[15] W.F. Manders, Holzforschung 41 (1987) 13-18.

[16] F.J. González-Vila, G. Almendros, J.C. del Río, F. Martín, A. Gutiérrez, J. Romero, J. Anal. Appl. Pyrol. 49 (1999) 295-305.

[17] A.T. Martínez, G. Almendros, F.J. González-Vila, R. Fründ, Solid State NMR 15 (1999) 41-48.

[18] J. Ralph, R.D. Hatfield, J. Agric. Food Chem. 39 (1991) 1426-1437.

[19] O. Faix, D. Meier, I. Fortmann, Holz Roh-Werkstoff 48 (1990) 351354.

[20] D. Meier, O. Faix, in: S.Y. Lin, C.W. Dence (Eds.), Methods in Lignin Chemistry, Springer, Berlin, 1992, pp. 177-199 (Chapter 4.7).

[21] H. Yokoi, Y. Ishida, H. Ohtani, S. Tsuge, T. Sonoda, T. Ona, Analyst 124 (1999) 669-674.

[22] H. Yokoi, T. Nakase, Y. Ishida, H. Ohtani, S. Tsuge, T. Sonoda, T. Ona, J. Anal. Appl. Pyrol. 57 (2001) 145-152.

[23] J. Rodrigues, D. Meier, O. Faix, H. Pereira, J. Anal. Appl. Pyrol. 48 (1999) 121-128.

[24] H. Nimz, Angew. Chem. Int. Ed. 13 (1974) 313-321.

[25] E. Adler, Wood Sci. Technol. 11 (1977) 169-218.

[26] T. Ona, T. Sonoda, K. Ito, M. Shibata, Jpn. Tappi 49 (1995) 15671576. 
[27] T. Ona, T. Sonoda, K. Ito, M. Shibata, Jpn. Tappi 49 (1995) 13471356.

[28] A. Wallis, R. Wearne, P. Wright, Appita J. 49 (1996) 427432.

[29] L.R. Schimleck, A.J. Michell, Tappi J. 81 (1998) 229-236.

[30] L.R. Schimleck, J. French, Appita J. 55 (2002) 149-154.
[31] P. Fardim, M.C. Ferreira, N. Duran, J. Wood Chem. Technol. 22 (2002) $67-81$.

[32] T. Ona, T. Sonoda, K. Ito, M. Shibata, T. Kato, Y. Ootake, J. Wood Chem. Technol. 17 (1997) 399-417.

[33] T. Ona, T. Sonoda, K. Ito, M. Shibata, T. Kato, Y. Ootake, Y. Tamai, Y. Kojima, J. Pulp Pap. Sci. 26 (2000) 43-47. 